\title{
Do Strict Capital Requirements Raise the Cost of Capital? Bank Regulation, Capital Structure and the Low Risk Anomaly
}

\section{Citation}

Baker, Malcolm, and Jeffrey Wurgler. "Do Strict Capital Requirements Raise the Cost of Capital? Bank Regulation, Capital Structure and the Low Risk Anomaly." American Economic Review: Papers and Proceedings 105, no. 5 (May 2015): 315-320.

\section{Published Version}

https://www.aeaweb.org/articles.php?doi=10.1257/aer.p20151092

\section{Permanent link}

http://nrs.harvard.edu/urn-3:HUL.InstRepos:16388336

\section{Terms of Use}

This article was downloaded from Harvard University's DASH repository, and is made available under the terms and conditions applicable to Open Access Policy Articles, as set forth at http:// nrs.harvard.edu/urn-3:HUL.InstRepos:dash.current.terms-of-use\#OAP

\section{Share Your Story}

The Harvard community has made this article openly available.

Please share how this access benefits you. Submit a story.

\section{Accessibility}




\section{Do Strict Capital Requirements Raise the Cost of Capital? Bank Regulation, Capital Structure, and the Low Risk Anomaly}

By MALCOLM BAKER AND JEFFREY WURGLER*

\begin{abstract}
* Baker: Harvard Business School, Baker Library 261, Boston, MA 02163 and NBER (e-mail: mbaker@hbs.edu); Wurgler: NYU Stern School of Business, 44 West $4^{\text {th }}$ Street, Suite 9-190, New York, NY 10012 and NBER (e-mail: jwurgler@stern.nyu.edu). We are grateful to Yakov Amihud, Jon Bernstein, Robin Greenwood, Alec Guzov, Victoria Ivashina, Randall Kroszner, Luc Leaven, Dave Lesmond, Thomas McGuire, Hamid Mehran, Justin Murfin, Antony Saunders, David Scharfstein, Amit Seru, Adi Sunderam, Jeremy Stein, Robert Turley, Sir John Vickers, Georgetown, Harvard Business School, HEC Montreal, MIT, NYU Stern, Tulane, University of Michigan, University of Notre Dame, Yale, the NBER, the Jackson Hole Finance Group, University of Chicago, Vienna University, and especially Sam Hanson. We thank Alex Guzov and Robert Turley for excellent research assistance. Baker gratefully acknowledges financial support from the Division of Research of the Harvard Business School. Baker and Wurgler also serve as consultants to Acadian Asset Management.
\end{abstract}

The financial crisis has led to stricter bank capital requirements, both globally via Basel III and in the U.S. through further constraints imposed by the Federal Reserve, and calls for further action. Setting these requirements requires balancing many costs and benefits, both social and private. In this paper, we argue that an important private cost has heretofore been neglected: All else equal, making regulated banks less risky may actually raise their cost of capital-with consequent implications for investment, growth, and the development of a shadow banking sector.
How can this be? Making equity less risky brings an overlooked "low risk anomaly" into play: Within the stock market, historical returns and thus realized costs of equity are higher, not lower, for less risky equity (e.g., Ang, Hodrick, Ying, and Yang 2006; Baker, Bradley, and Wurgler 2011). As any such anomaly is much weaker in the debt markets, Modigliani-Miller capital structure irrelevance fails (even absent other frictions), and banks' weighted average cost of capital becomes inversely related to leverage. ${ }^{1}$

After background on the low risk anomaly, we use a large sample of US bank returns and capital structure data to illustrate, first, that bank equity risk decreases with leverage, and, second, that the anomaly is present banks. A calibration that puts the two pieces together suggests that a large increase in capital requirements could, via the low risk anomaly, meaningfully increase banks’ cost of capital.

To be sure, when all social and private benefits and costs are weighed, stricter capital

\footnotetext{
1 The discussion and evidence in this paper are specialized to banks. See Baker and Wurgler (2014) for a general treatment of the low risk anomaly's implications for capital structure, including how it can be used to generate a tradeoff theory of leverage.
} 
requirements may well remain desirable. The argument here is that one cost has been neglected and should be added to the debate.

\section{The Low Risk Anomaly}

Multiple Nobel Prizes, hundreds of textbooks, thousands of papers, and millions of classroom hours have incorporated the notion that risk is rewarded by expected return. Across asset classes, this holds. In long-term US data, for example, stocks provided higher but more variable returns than long-term corporate bonds, which in turn provided higher but riskier returns than longterm Treasuries, and so on.

The historical risk-return tradeoff within the stock market has been flat or inverted, however. The standard Capital Asset Pricing Model (CAPM) predicts that the expected return on a security is proportional to its systematic risk (beta). The low risk anomaly is the pattern that stocks with lower beta, or even idiosyncratic risk, have earned higher returns. This anomaly appears whether returns are risk-adjusted or, in some cases, even if they are not. It appears not just in the US but also in each G7 country and across 23 developed markets (Ang et al. 2009, Baker et al. 2014).

This paper and several others consider the possibility that the failure of the CAPM reflects inefficient asset pricing, not model misspecification of risk. Some investors may have an overconfidence- or lottery-based preference for volatile or skewed investments (Cornell 2008; Kumar 2009; Bali, Cakici, and Whitelaw 2011; Barberis and Huang 2008). Leverage-constrained investors seeking high returns from beta risk may also want high beta stocks (Frazzini and Pedersen 2014).

If "arbitrageurs" cannot meet such demand, overpricing of high beta stocks will result, the observable implication of which is abnormally low future returns on high beta stocks. For firms, this means a low cost of equity relative to that of less risky, low beta issues.

For a variety of reasons, such arbitrage is indeed likely to be limited. The most plausible "arbitrageurs" in practice, professional fund managers, may prefer high-beta stocks themselves because the inflows to performing well in rising markets exceed the outflows to performing poorly in falling markets (Karceski 2002). In addition, fund manager performance is often defined as return relative to "the market" on a non-beta-adjusted basis. This leads managers to avoid low beta stocks (Baker et al. 2011). More generally, the extra costs of shorting inhibit any effort to exploit overpricing (Hong and Sraer 2014).

\section{Step One: Reducing Leverage Reduces Risk}


We focus on beta as our measure of equity risk, although the evidence supports a separate idiosyncratic risk anomaly. As in the CAPM, beta is defined as the covariance of returns with the market risk premium, divided by the variance of the market risk premium.

We first review how equity risk will change with a change in leverage. Rearranging overall asset beta, which is defined as a weighted average of equity and debt betas, with $e$ being the ratio of equity to total assets, yields

(1) $\beta_{e}=\frac{1}{e} \beta_{a}-\left(\frac{1}{e}-1\right) \beta_{d}$.

With approximately riskless debt, the relationship between equity beta and leverage is linear with a slope equal to asset beta.

Confirming Equation (1) requires returns and capitalization data. Our returns sample of 272,031 total bank-months includes 3,952 publicly traded banks or holding companies that appear in the Center for Research on Security Prices (CRSP) data between February 1970 and December 2011. Before 1970, there are few traded banks, rendering the beta portfolios highly volatile.

We estimate equity betas by regressing a minimum of 24 months and a maximum of 60 months of excess returns on the corresponding CRSP excess value-weighted market returns. For each bank we compute a forward or realized beta, based on future returns data, to study how leverage today translates into systematic risk. We also compute a backward or pre-ranking beta, based on past returns.

Bank equity betas are relatively low, with pre-ranking means and medians around 0.67, but there is significant variation. The median pre-ranking beta among the bottom three deciles is 0.21 and the mean among the top three is 1.27 . This spread leads to differences in realized betas of approximately 0.6. See online materials for more summary statistics.

For a subset of bank-months we can obtain leverage data from the Wharton Research Data Services (WRDS) Bank Regulatory database of Federal Reserve Bank call reports. The measure most closely watched by regulators is the Tier 1 ratio, defined as common stock plus retained earnings divided by risk-weighted assets. This subsample of 74,105 bank-months runs from March 1996, the first date Tier 1 capital is available, through February 2011.

There is also variation in Tier 1 ratios across banks. The median in the bottom three deciles is 9.30 percent, versus 13.94 percent in the top three deciles and 17.26 in the top decile.

\section{[ Insert Figure 1 Here ]}

Figure 1 fits a kernel regression of (forward) equity beta on the inverse Tier 1 ratio, our measure of $1 / e$ in Equation (1). A linear regression with an intercept forced to zero, 
corresponding to the assumption of riskless debt, yields a slope and estimate of asset beta of 0.074 . (The asset beta estimate will be useful in the calibration results).

The inclusion of extreme levels of leverage generates a modest S-shape. At high levels of leverage, debt shares some of the risk of equity. Also, when asset betas differ across banks, those with less risky assets will choose high leverage and vice-versa. Finally, the Tier 1 ratio is one of several regulated measures of leverage, leading to attenuation bias.

These effects tend to flatten the crosssectional relationship between leverage and risk. We can thus view 0.074 as a plausible lower bound of the asset beta of a typical bank and thus a lower bound of the effect of an exogenous change in leverage on equity beta.

\section{Step Two: Reducing Risk Increases the Cost of Equity}

We incorporate the low risk anomaly by supposing that the CAPM holds for stocks and bonds except that in the case of stocks, there is an anomaly in which higher beta equities underperform their CAPM benchmark and lower beta equities outperform it, as in

(2) $r_{e}=\gamma\left(\beta_{e}-1\right)+r_{f}+\beta_{e} r_{p}$

where $r_{f}$ is the risk free rate, $r_{p}$ is the market risk premium, and $\alpha$ is shorthand for the first term which is not present in the CAPM. The extent of the low risk anomaly, and a central parameter of interest, is $\gamma=d \alpha / d \beta_{e}<0$.

We assume that debt is correctly priced as (3) $r_{d}=r_{f}+\beta_{d} r_{p}$ so the weighted-average cost of capital is (4) $W A C C=e r_{e}+(1-e) r_{d}=$ $r_{f}+\beta_{a} r_{p}+\gamma \beta_{a}-\gamma\left[e+(1-e) \beta_{d}(e)\right]$ using Equation (1) to substitute out $\beta_{e}$.

We are interested in how WACC changes upon moving from a level of capital $e$ to a new regulatory level of $e^{*}$. The difference between Equation (4) evaluated at the new and old levels of capital leads to an increase of

(5) $\triangle W A C C=\gamma\left[e-e^{*}+(1-e) \beta_{d}(e)+\right.$ $\left.(1-e) \beta_{d}\left(e^{*}\right)\right]$.

A special case is when the debt is riskless in both capital regimes, i.e., debt betas are zero. Then the change in the cost of capital is simply $\gamma\left(e-e^{*}\right)$, which is greater than zero for increases in $e$. Riskless debt is a reasonable approximation for banks. Estimates of their asset beta are on the order of 0.10 , as we have seen, so estimates of debt betas are by definition lower. For a plausible change in leverage, the change in debt beta is lower still.

\section{[ Insert Table 1 Here ]}

Our benchmark is riskless debt, segmented equity and debt markets, and no government subsidy. Table 1 summarizes the effects of relaxing these assumptions. In particular, if 
there is an equally large low risk anomaly in corporate debt, leverage irrelevance is restored. Frazzini and Pedersen (2014) and Baker and Wurgler (2014), however, find that any anomaly in debt is far smaller. We also consider when a smaller low risk anomaly exists in debt markets, with a new Equation (3) that mirrors Equation (2) with parameters $\gamma_{d}$ and $\overline{\beta_{d}}$ in place of $\gamma$ and 1 ; and when the government insures bank debt, so that the cost of debt in Equation (3) is simply $r_{d}=r_{f}$, regardless of risk. There are simplifying cases when $\gamma_{d}=\gamma$ and when $\gamma=-r_{p}$.

We now empirically confirm that there is a low risk anomaly in banks: $\gamma=d \alpha / d \beta_{e}<0$ in terms of Equation (2). Figure 2 reports the results of the following exercise. We compute monthly returns on six portfolios: the top three, middle four, and bottom three preranking CAPM beta portfolios, where the portfolio returns are either equal- or equity market capitalization-weighted within groups. We then regress portfolios' excess returns on market excess returns to compute and plot betas and alphas. We repeat the process using the Fama-French model, which controls for comovement patterns associated with market capitalization and book-to-market equity.

[ Insert Figure 2 Here ]
The figure allows us to estimate $\gamma$, the strength of the anomaly, as 68 basis points per month based on the CAPM beta (annualized 8.5 percent) and 75 basis points per month for the Fama-French market beta (annualized 9.8 percent). For an investor, these are large differences in risk-adjusted returns; for a firm, they are large differences in the cost of equity.

In one of several robustness checks (available in online materials), we link leverage and risk-adjusted returns directly, rather than through the two-step process illustrated in Figures 1 and 2. This helps deal with the possibility that the low risk anomaly is relevant only for variation in beta that does not come from leverage changes. We find a larger but statistically weaker effect, which is not surprising since leverage data allow use of only a third of the full returns series.

\section{Calibration}

We now estimate the change in the cost of capital that would result from a binding shift in capital requirements of ten percentage points, as considered in Kashyap et al. (2010). This is a large change in the context of existing regulation-Basel III raised the Tier 1 ratio from 8 percent to between 8.5 and 11 percent-but far smaller than the increase to 20 or 30 percent proposed by Admati and Hellwig (2013). 
We have seen how the low volatility anomaly in bank stocks means that capital requirements may increase their weighted average cost of capital. In the benchmark case of riskless debt (in both capital regimes), segmented markets, and no government subsidy, as in the first line of Table 1 , the magnitude is simply the excess risk-adjusted performance per unit of beta times the percentage point increase in equity capital. Estimates of the former range from 68 to 75 basis points per month, so the midpoint of these implies an annualized $71 \times 12 \times 10=85$ basis point increase in the cost of capital. In competitive lending markets, borrowing costs would increase by this amount.

To put 85 basis points in perspective, recall that our asset beta estimate for banks was 0.074 . With the historical market risk premium from Ken French's data library of 45 basis points per month over our returns sample period, this suggests an annualized pre-tax weighted average cost of capital under the CAPM of $45 \times 12 \times 0.074=40$ basis points per year above the risk-free rate. The presence of the low volatility anomaly thus implies a tripling of regulated banks' pretax weighted average cost of capital from 40 to 125 basis points over the riskless rate.

The simplifying assumptions behind this estimate suggest moderating this conclusion, however. If our estimate of asset beta is too low and debt is risky, their betas have further to fall. Although this effect is probably slight, the change in equity betas is mitigated by the extent to which debt was already sharing the risk with equity. Similarly, government insurance of debt implies that debt was already sharing risk with equity. In addition, and although the evidence in Baker and Wurgler (2014) cast doubts on a fully integrated low risk anomaly in corporate debt, to the extent it is present it also reduces the impact of changes in leverage. And, finally and most obviously, our estimate of the low risk anomaly may be too large to apply to policy decisions going forward. Despite plausible theoretical foundations and statistical robustness, the anomaly's future may not follow its past. But to the extent that it does, it is a cost that needs to be included in debates about capital regulation.

\section{REFERENCES}

Admati, Anat R., and Martin Hellwig. 2013. The Bankers' New Clothes. Princeton UP. Ang, Andrew, Robert Hodrick, Yuhang Xing, and Xiaoyan Zhang. 2006. "The CrossSection of Volatility and Expected Returns." Journal of Finance 61: 259-299.

Ang, Andrew, Robert Hodrick, Yuhang Xing, and Xiaoyan Zhang. 2009. "High 
Idiosyncratic Volatility and Low Returns: International and Further U.S. Evidence.” Journal of Financial Economics 91: 1-23.

Baker, Malcolm, Brendan Bradley, and Ryan Taliaferro. 2011. "The Low-Risk Anomaly: A Decomposition into Micro and Macro Effects.” Financial Analysts Jnl 70: 43-58.

Baker, Malcolm, Brendan Bradley, and Jeffrey Wurgler. 2011. "Benchmarks as Limits to Arbitrage: Understanding the Low-Volatility Anomaly.” Financial Analysts Journal 67: 40-54.

Baker, Malcolm, and Jeffrey Wurgler. 2014. "The Risk Anomaly Tradeoff of Leverage." Harvard University working paper.

Bali, Turan, Nusret Cakici, and Robert Whitelaw. 2011. "Maxing Out: Stocks as Lotteries and the Cross-Section of Expected Returns." Journal of Financial Economics 99: 427-446.

Barberis, Nicholas, and Ming Huang. 2008 "Stocks as Lotteries: The Implications of Probability Weighting for Security Prices.” American Economic Review 98: 2066-2100. Cornell, Bradford. 2008. "The Pricing of Volatility and Skewness: A New Interpretation.” California Institute of Technology working paper.

Frazzini, Andrea, and Lasse Pedersen. 2014.

"Betting Against Beta." Journal of Financial Economics 111 (1): 1-25.
Hong, Harrison, and David Sraer. 2014. "Speculative Betas." Princeton University working paper.

Karceski, Jason. 2002. "Returns-Chasing Behavior, Mutual Funds, and Beta’s Death.” Journal of Financial and Quantitative Analysis 37: 559-594.

Kashyap, Anil K., Jeremy C. Stein, and Samuel Hanson. 2010. "An Analysis of the Impact of 'Substantially Heightened' Capital Requirements on Large Financial Institutions." Harvard Univ working paper. Kumar, Alok. 2009. "Who Gambles in the Stock Market?” Journal of Finance 64: 1889-1933. 


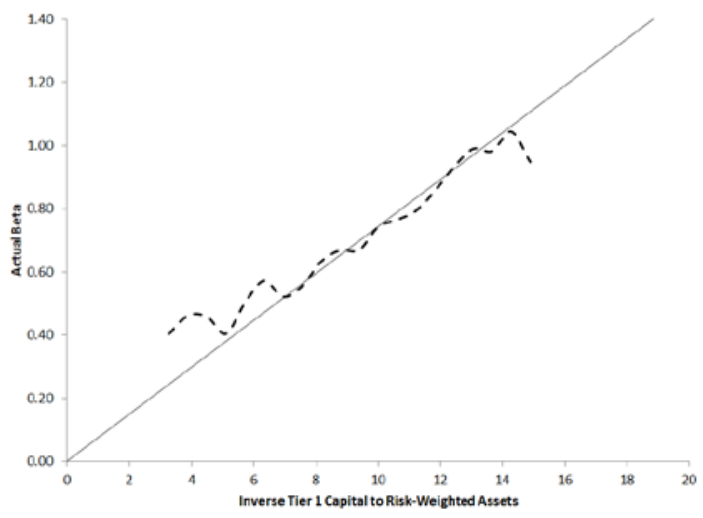

FIGURE 1. BETA AND BANK LEVERAGE

Note: The sample includes 74,105 bank-months of data from March 1996 to February 2011. The dependent variable is forward beta, computed by regressing a minimum of 24 months and a maximum of 60 months of future holding period returns on the corresponding bank's CRSP valueweighted market returns, both in excess of the riskless rate. The independent variable is the ratio of total risk-based capital to Tier 1 capital. The local polynomial regressions use a Epanechnikov kernel with 20 bins and smoothing interval of 0.1 . 


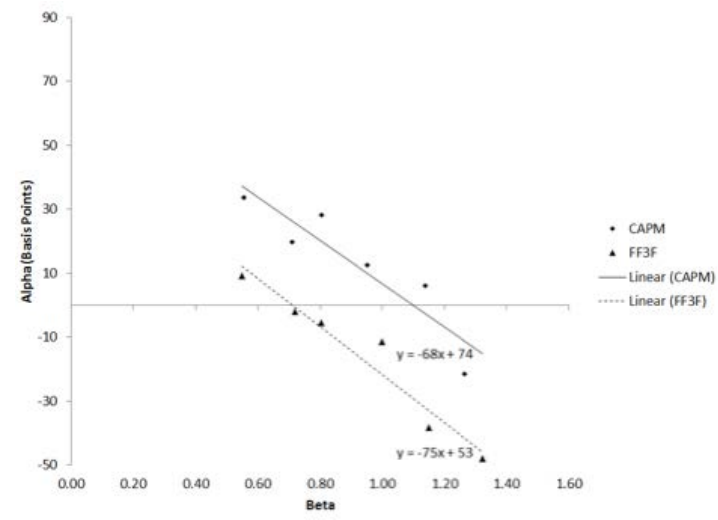

FIGURE 2. BETA AND THE COST OF EQUITY: THE LOW RISK ANOMALY IN BANKS

Note: The sample includes 486 months of portfolio returns from July 1971 to December 2011. The points are excess portfolio returns relative to CAPM or Fama-French three-factor model predictions. The six portfolios for each model are based on equal- and capitalization-weighted versions of the top three, middle four, and bottom three deciles according to pre-ranking beta. 
TABLE 1-DETERMINANTS OF CHANGES IN WACC.

\begin{tabular}{|c|c|c|c|c|}
\hline \multicolumn{4}{|c|}{ Bank Debt } & \multirow[b]{2}{*}{$\triangle W A C C$} \\
\hline Risk & Pricing & $\begin{array}{l}\text { Integrated } \\
\text { Markets }\end{array}$ & $\begin{array}{l}\text { Government } \\
\text { Subsidy }\end{array}$ & \\
\hline Risky & Correctly Priced & No & No & $\gamma\left(e-e^{*}+A\left(e, e^{*}\right)\right)$ \\
\hline Risk Free & Correctly Priced & No & No & $\gamma\left(e-e^{*}\right)$ \\
\hline Risky & Low Beta Anomaly & No & No & $\left(\gamma-\overline{\beta_{d}} \gamma_{d}\right)\left(e-e^{*}\right)+\left(\gamma-\gamma_{d}\right) A\left(e, e^{*}\right)$ \\
\hline Risky & $\begin{array}{l}\text { Low Beta Anomaly } \\
\gamma=\gamma_{d}\end{array}$ & No & No & $\gamma\left(1-\overline{\beta_{d}}\right)\left(e-e^{*}\right)$ \\
\hline $\begin{array}{l}\text { Risky or Risk } \\
\text { Free }\end{array}$ & Low Beta Anomaly & Yes & No & 0 \\
\hline Risky & Correctly Priced & No & Yes & $\gamma\left(e-e^{*}\right)+\left(\gamma+r_{p}\right) A\left(e, e^{*}\right)$ \\
\hline Risky & Correctly Priced & No & $\begin{array}{l}\text { Yes } \\
\gamma=-r_{p}\end{array}$ & $\gamma\left(e-e^{*}\right)$ \\
\hline
\end{tabular}

Notes: $\overline{\beta_{d}}$ refers to the mean corporate debt beta and $\gamma_{d}$ refers to the size of the low risk anomaly, playing the roles of $\gamma$ and the mean equity beta of unity in Equation (2). Also, to simplify notation, we define $A\left(e, e^{*}\right) \equiv(1-e) \beta_{d}(e)-\left(1-e^{*}\right) \beta_{d}\left(e^{*}\right) \geq 0$. 